\title{
Prevalence and antimicrobial susceptibility profile of Streptococcus agalactiae in pregnant women seen at the University Hospital of Londrina, Paraná, Brazil
}

\section{Prevalência e sensibilidade aos antimicrobianos de Streptococcus agalactiae em gestantes atendidas no Hospital Universitário de Londrina, Paraná, Brazil}

Ana Elisa Belotto Morguette ${ }^{1}$, Renata Perugini Biasi-Garbin², Eliane Saori Otaguiri², Marcia Regina Eches Perugini ${ }^{3}$, Marsileni Pelisson ${ }^{4}$, Floristher Elaine Carrara-Marroni ${ }^{5}$, Eliana Carolina Vespero $^{6}$, Renata Aparecida Belei ${ }^{7}$, Gilselena Kerbauy ${ }^{8}$, Jaqueline Dario Capobiango ${ }^{9}$, Lucy Megumi Yamauchi ${ }^{10}$, Sueli Fumie Yamada-Ogatta ${ }^{11}$

\begin{abstract}
A retrospective study of pregnant women seen at the University Hospital of Londrina, Paraná, Brazil was performed to determine the prevalence of Group B Streptococcus (GBS) vaginal-rectal colonization, and the GBS susceptibility for antimicrobials used in intrapartum antibiotic prophylaxis. A vaginal-rectal swab was collected from 2,901 women between 35 and 37 weeks of gestation. Of these, $527(18.2 \%)$ had a positive culture for GBS, and $0.4 \%, 10.2 \%$ and $10 \%$ of the isolates were resistant to penicillin, erythromycin and clindamycin, respectively. These results highlight the importance of continuous surveillance of GBS colonization in pregnant women for preventing GBS infections in neonates.
\end{abstract}

Keywords: Streptococcus agalactiae. Colonization. Antimicrobial resistance. Prevalence.

\section{Resumo}

Um estudo retrospectivo foi realizado com gestantes atendidas no Hospital Universitário de Londrina, Paraná, Brasil para determinar a prevalência de colonização vaginal-retal por estreptococos do Grupo B (EGB) e o perfil de sensibilidade de EGB aos antimicrobianos utilizados para a antibioticoterapia profilática intraparto. Swabs vaginais-retais foram coletados de 2.901 mulheres entre a $35^{\mathrm{a}}$ e $37^{\mathrm{a}}$ semana de gestação. Destes, $527(18,2 \%)$ apresentaram cultura positiva para EGB, e $0,4 \%, 10,2 \%$ e $10 \%$ dos

\footnotetext{
${ }^{1}$ Mestranda do Programa de Pós-Graduação em Microbiologia da Universidade Estadual de Londrina, Londrina, Paraná, Brasil. Departamento de Microbiologia do Centro de Ciências Biológicas da Universidade Estadual de Londrina, Londrina, Paraná, Brasil.

${ }^{2}$ Doutoranda em Microbiologia pela Universidade Estadual de Londrina, Londrina, Paraná, Brasil. Departamento de Microbiologia do Centro de Ciências Biológicas da Universidade Estadual de Londrina, Londrina, Paraná, Brasil.

${ }^{3}$ Doutorado em Doenças Infecciosas e Parasitárias pela Universidade de São Paulo, São Paulo, Brasil. Professor associado do Laboratório de Análises Clínicas, Setor de Microbiologia do Hospital Universitário da Universidade Estadual de Londrina, Londrina, Paraná, Brasil.

${ }^{4}$ Mestrado em Microbiologia pela Universidade Estadual de Londrina, Londrina, Paraná, Brasil. Departamento de Patologia, Análises Clínicas e Toxicológicas, Centro de Ciências da Saúde, Universidade Estadual de Londrina, Londrina, Paraná, Brasil.

${ }^{5}$ Doutorado em Microbiologia pela Universidade Estadual de Londrina, Londrina, Paraná, Brasil. Professor adjunto do Departamento de Patologia, Análises Clínicas e Toxicológicas, Centro de Ciências da Saúde, Universidade Estadual de Londrina, Londrina, Paraná, Brasil.

${ }^{6}$ Doutorado em Microbiologia pela Universidade Estadual de Londrina, Londrina, Paraná, Brasil. Departamento de Patologia, Análises Clínicas e Toxicológicas, Centro de Ciências da Saúde, Universidade Estadual de Londrina, Londrina, Paraná, Brasil.

Doutorado em Educação pela Universidade Estadual Paulista Júlio de Mesquita Filho, Marília, São Paulo, Brasil. Departamento de Enfermagem, Centro de Ciências da Saúde da Universidade Estadual de Londrina, Londrina, Paraná, Brasil.

${ }^{8}$ Doutorado em Microbiologia pela Universidade Estadual de Londrina, Londrina, Paraná, Brasil. Professor adjunto do Departamento de Enfermagem do Centro de Ciências da Saúde da Universidade Estadual de Londrina, Londrina, Paraná, Brasil.

${ }^{9}$ Doutorado em Ciências da Saúde pela Universidade Estadual de Londrina, Londrina, Paraná, Brasil. Departamento de Clínica Médica do Centro de Ciências da Saúde da Universidade Estadual de Londrina, Londrina, Paraná, Brasil.

${ }^{10}$ Doutorado em Imunologia Básica e Aplicada pela Universidade de São Paulo, Ribeirão Preto, São Paulo, Brasil. Departamento de Microbiologia do Centro de Ciências Biológicas da Universidade Estadual de Londrina, Londrina, Paraná, Brasil.

${ }^{11}$ Doutorado em Biologia Celular e Molecular pela Fundação Oswaldo Cruz, Curitiba, Paraná, Brasil. Departamento de Microbiologia do Centro de Ciências Biológicas da Universidade Estadual de Londrina, Londrina, Paraná, Brasil. E-mail: ogatta@uel.br
} 
isolados foram resistentes à penicilina, eritromicina e clindamicina, respectivamente. Estes resultados destacam a importância de vigilância contínua da colonização por EGB em gestantes para a prevenção de infecções em neonatos por EGB.

Palavras chave: Streptococcus agalactiae. Colonização. Resistência antimicrobiana. Prevalência.

\section{Introduction}

Streptococcus agalactiae (group B Streptococcus - GBS) can be found as a harmless colonizer of the human microbiota, mainly in the gastrointestinal and genitourinary tract. ${ }^{(1)}$ Vaginal-rectal GBS colonization in pregnant women is usually asymptomatic, but increases the risk of preterm birth and vertical transmission to newborns. ${ }^{(2)}$ Importantly, around 1-3\% of neonates colonized during delivery may develop early-onset GBS diseases, ${ }^{(3,4)}$ which are associated with high mortality rates or long-term disabilities such as serious neurological sequelae. ${ }^{(5,6)}$

Preventive universal strategies for detecting GBS vaginal-rectal colonization in pregnant women at 35 and 37 weeks of gestation and administration of intrapartum antibiotic prophylaxis (IAP) led to a significant reduction in the incidence of GBS early neonatal infections in many parts of the world.(7) Currently, the antenatal strategy for detecting GBS colonization recommended by Center for Diseases Control of the United States ${ }^{(4)}$ is based on culture methods, and penicillin is the first-line for IAP. In penicillin-allergic pregnant women with high risk of anaphylaxis, erythromycin, clindamycin or vancomycin are recommended as alternatives. However, this prevention strategy is yet to be adopted by most of the underdeveloped or developing countries. ${ }^{(6)}$ In Brazil, although the Brazilian Society of Gynecology and Obstetrics recommends the GBS screening and IAP in colonized pregnant women, there is no consensus regarding prophylactic measures to reduce the incidence of neonatal GBS infection.

In that sense, GBS detection and determination of susceptibility profile on recommended gestational period should be expanded at health care services to perform the IAP properly, as an attempt to reduce the risk of both bacterial transmission to newborns and development of resistance to commercially available antibiotics. Therefore, the present study aimed to evaluate the prevalence and antimicrobial susceptibility profile of GBS isolated from pregnant women seen at the University Hospital of Londrina in northern Paraná, Brazil.

\section{Material and Method}

\section{Patients and study design}

This retrospective study based on medical record review was conducted at the University Hospital of Londrina (UHL) between January 2014 and December 2016. This hospital is the major referral center for the "Sistema Único de Saúde (SUS)", the Brazilian governmental health system, in northern Paraná, Brazil. Besides the population of Londrina and neighboring municipalities, this hospital is also a reference for tertiary care for individuals from several localities in the states of São Paulo and Mato Grosso do Sul. UHL has adopted the CDC recommendations to prevent GBS early-onset diseases in neonates. Penicillin (first-line), and clindamycin or vancomycin (secondlines) were used for IAP. ${ }^{(4)}$ Vaginal-rectal swabs were collected from all pregnant women between the $35^{\text {th }}$ and $37^{\text {th }}$ weeks of gestational age seen at the hospital. Sampling was performed on the lower third of vagina followed by the rectum using COPAN Transystem Stuart collection device (COPAN Diagnostic, Italy) and immediately transported to the microbiology laboratory. Data from AGTA healthcare information system database, LABHOS $^{\circledR}$ module indicated that 2,901 pregnant women were seen at the UHL during the analyzed period. The study protocols were approved by the Ethics Committee of Universidade Estadual de Londrina (Document 193/12-CEP/UEL).

\section{Microbiological analysis}

The swab specimens were inoculated into Granada Biphasic broth (bioMérieux, Brazil) and incubated at $37^{\circ} \mathrm{C}$ for 24 hours, in accordance with the hospital routine. After incubation, the samples were subcultured on Muller-Hinton agar (MHA) containing 5\% sheep blood at $37^{\circ} \mathrm{C}$ for 24 hours. All isolates were identified to the species level by standard phenotypic methods based on colony morphology, Gram staining, catalase and CAMP (Christie, Atkins, Munch-Petersen) tests. Bacteria were kept at $-20^{\circ} \mathrm{C}$ in TSB containing $20 \%$ glycerol and 5\% sheep blood.

All GBS isolates were tested for penicillin G, clindamycin and erythromycin (Oxoid ${ }^{\mathrm{TM}}$, Brazil) 
susceptibility using the disk diffusion method following the recommendations of the Clinical and Laboratory Standards Institute. ${ }^{(8)}$ Streptococcus pneumoniae ATCC 49619 was used as the quality control of the assays.

\section{Results and Discussion}

Vaginal-rectal GBS colonization in pregnant and non-pregnant women can be transient, intermittent or persistent..$^{(2)}$ Accordingly, the risk of maternal GBS transmission to newborn as well as development of early-onset infection have been maintained overtime. Therefore, continuous surveillance of vaginal GBS carriage in pregnant women is essential for prevention of neonatal GBS diseases.

The prevalence rates of GBS colonization in pregnant women vary between geographic regions, with the lowest and highest prevalence of colonization in Asia (11.1\%) and Africa (22.4\%), respectively. Although this regional heterogeneity is not fully understood, it does not seem to be due to the differences in culture methods or in the timing of vaginal-rectal swab collection in pregnancy. ${ }^{(9)}$

In this study, 2,901 pregnant women $(1,137,820$ and 944 during 2014, 2015 and 2016, respectively) with no clinical evidence of streptococcal infection were included. Of these, 528 (18.2\%) had a positive culture for GBS, which is in accordance with the average prevalence of $19.7 \%$ previously reported for countries in the Americas. ${ }^{(9)}$ The GBS colonization prevalence in pregnant women did not vary significantly $(P>$ $0.05)$ over the analysis period, ranging between $17.7 \%$ (201/1137), $19.0 \%(156 / 820)$ and 18.0\% (170/944) in 2014, 2015 and 2016, respectively (Table 1). Overall, the average age of pregnant women was 27 years (ranging from 13 to 54 years) and there were no significant differences $(P>0.05)$ in the prevalence of GBS colonization between age groups (Table 2). In Brazil, differences in the prevalence of GBS colonization in pregnant women have also been detected according to the geographic region and the data are summarized in Table 3.
Tabela 1 - Antimicrobial susceptibility profile of GBS isolated from pregnant women seen at UHL from January 2014 to December 2016.

\begin{tabular}{|c|c|c|c|c|c|c|c|c|c|}
\hline \multirow{4}{*}{ Year } & \multirow{4}{*}{$N$} & \multirow{4}{*}{$n(\%)$} & \multicolumn{7}{|c|}{ Antimicrobial } \\
\hline & & & \multicolumn{2}{|c|}{ Penicilin } & \multicolumn{3}{|c|}{ Erythromycin } & \multicolumn{2}{|c|}{ Clindamycin } \\
\hline & & & S & $\mathrm{R}$ & S & I & $\mathrm{R}$ & S & $\mathrm{R}$ \\
\hline & & & $\begin{array}{c}n \\
(\%)\end{array}$ & $\begin{array}{c}n \\
(\%)\end{array}$ & $\begin{array}{c}n \\
(\%)\end{array}$ & $\begin{array}{c}n \\
(\%)\end{array}$ & $\begin{array}{c}n \\
(\%)\end{array}$ & $\begin{array}{c}n \\
(\%)\end{array}$ & $\begin{array}{c}n \\
(\%)\end{array}$ \\
\hline 2014 & 1137 & $\begin{array}{c}201 \\
(17.7)\end{array}$ & $\begin{array}{c}201 \\
(100)\end{array}$ & 0 & $\begin{array}{c}168 \\
(83.6)\end{array}$ & $\begin{array}{c}5 \\
(2.5)\end{array}$ & $\begin{array}{c}28 \\
(13.9)\end{array}$ & $\begin{array}{c}170 \\
(84.6)\end{array}$ & $\begin{array}{c}31 \\
(15.4)\end{array}$ \\
\hline 2015 & 820 & $\begin{array}{c}156 \\
(19.2)\end{array}$ & $\begin{array}{c}154 \\
(98.7)\end{array}$ & $\begin{array}{c}2 \\
(1.3)\end{array}$ & $\begin{array}{c}135 \\
(86.0)\end{array}$ & $\begin{array}{c}6 \\
(3.8)\end{array}$ & $\begin{array}{c}15 \\
(9.6)\end{array}$ & $\begin{array}{c}143 \\
(91.7)\end{array}$ & $\begin{array}{c}13 \\
(8.3)\end{array}$ \\
\hline 2016 & 944 & $\begin{array}{c}170 \\
(18.0)\end{array}$ & $\begin{array}{c}170 \\
(100)\end{array}$ & 0 & $\begin{array}{c}154 \\
(90.0)\end{array}$ & $\begin{array}{c}6 \\
(3.5)\end{array}$ & $\begin{array}{c}11 \\
(6.5)\end{array}$ & $\begin{array}{c}161 \\
(94.7)\end{array}$ & $\begin{array}{c}9 \\
(5.3)\end{array}$ \\
\hline Total & 2901 & $\begin{array}{c}528 \\
(18.2)\end{array}$ & $\begin{array}{c}526 \\
(99.6)\end{array}$ & $\begin{array}{c}2 \\
(0.4)\end{array}$ & $\begin{array}{c}457 \\
(86.6)\end{array}$ & $\begin{array}{c}17 \\
(3.2)\end{array}$ & $\begin{array}{c}54 \\
(10.2)\end{array}$ & $\begin{array}{c}475 \\
(90.0)\end{array}$ & $\begin{array}{c}53 \\
(10.0)\end{array}$ \\
\hline
\end{tabular}

$N$ : number of pregnant woman seen at UHL during the analyzed period; $n$ : number of positive cultures for GBS; S: susceptible; I: intermediate; $\mathrm{R}$ : resistant

Tabela 2 - Age groups of pregnant women positive for vaginal-rectal GBS colonization seen at UHL from January 2014 to December 2016.

\begin{tabular}{ccccccc}
\hline \multirow{2}{*}{ Age group } & \multicolumn{2}{c}{2014} & \multicolumn{2}{c}{2015} & \multicolumn{2}{c}{2016} \\
\cline { 2 - 7 } & $N$ & $\%$ & $N$ & $\%$ & $N$ & $\%$ \\
\hline$<20$ years & 41 & 20.4 & 29 & 18.6 & 24 & 14.1 \\
20 to 24 years & 25 & 12.4 & 44 & 28.2 & 44 & 25.9 \\
25 to 29 years & 53 & 26.4 & 27 & 17.3 & 35 & 20.6 \\
30 to 34 years & 39 & 19.4 & 22 & 14.1 & 36 & 21.2 \\
$>35$ years & 43 & 21.4 & 34 & 21.8 & 31 & 18.2 \\
\hline Total & 201 & 100 & 156 & 100 & 170 & 100 \\
\hline
\end{tabular}

$N$ : number of pregnant women seen at UHL during the analyzed period

Currently the use of intravenous penicillin G remains the first-line antibiotic for the IAP.(7) The decrease in susceptibility to penicillin in GBS is rare, and $100 \%$ of penicillin-sensitive isolates were found in several regions of the world. ${ }^{(10-13)}$ However, GBS isolates with decreased susceptibility to penicillin were previously described. This phenomenon occurs due to the accumulation of mutations in the penicillinbinding proteins PBP1, PBP2b and PBP2x, which participate in cell wall biosynthesis. ${ }^{(14)}$ In this study, we detected only two isolates $(0.4 \%)$ resistant to 
penicillin. In Brazil, most of the GBS isolates remain sensitive to penilicin. Nonetheless, high-rate resistance to this antibiotic was detected in GBS isolated from pregnant women seen at a maternity facility in Sobral, Ceará (Table 3).

Tabela 3 - Prevalence of GBS colonization among pregnant women reported in Brazilian studies.

\begin{tabular}{|c|c|c|c|c|c|c|}
\hline City/State & $N$ & $\begin{array}{l}\text { Site/Timing } \\
\text { of swab } \\
\text { collection }\end{array}$ & Enrichment medium & $n(\%)$ & $\begin{array}{l}\text { Antimicrobial } \\
\text { resistance }(\%)\end{array}$ & Reference \\
\hline $\begin{array}{c}\text { Rio de } \\
\text { Janeiro/RJ }\end{array}$ & 86 & $\mathrm{~V} / \mathrm{NE}$ & $\begin{array}{c}\text { TH }+5 \% \text { sheep blood }+\mathrm{CN} \\
8 \mu \mathrm{g} / \mathrm{mL}+\mathrm{NA} 15 \mu \mathrm{g} / \mathrm{mL}\end{array}$ & $\begin{array}{c}22 \\
(25.6)\end{array}$ & NT & $\begin{array}{l}\text { Benchetrit et } \\
\text { al., 1982 }\end{array}$ \\
\hline Londrina/PR & 309 & $\begin{array}{l}\mathrm{VR} / \geq 36 \\
\text { weeks }\end{array}$ & НPTH & $\begin{array}{c}46 \\
(14.9)\end{array}$ & NT & $\begin{array}{l}\text { Beraldo et al., } \\
2004^{(16)}\end{array}$ \\
\hline $\begin{array}{l}\text { Florianópolis/ } \\
\text { SC }\end{array}$ & 273 & $\begin{array}{l}\mathrm{VR} / \geq 35 \\
\text { weeks }\end{array}$ & $\begin{array}{c}\mathrm{TH}+\mathrm{CT} 10 \mu \mathrm{g} / \mathrm{mL}+\mathrm{NA} 15 \mu \mathrm{g} / \\
\mathrm{mL}\end{array}$ & $\begin{array}{c}59 \\
(21.6)\end{array}$ & NT & $\begin{array}{l}\text { Pogere et al., } \\
2005^{(17)}\end{array}$ \\
\hline $\begin{array}{l}\text { Ribeirão } \\
\text { Preto/SP }\end{array}$ & 598 & $\begin{array}{l}\mathrm{V} / 35-37 \\
\text { weeks }\end{array}$ & $\begin{array}{c}\text { LIM'S+CT } 10 \mu \mathrm{g} / \mathrm{mL}+\mathrm{NA} \\
15 \mu \mathrm{g} / \mathrm{mL}\end{array}$ & $\begin{array}{c}107 \\
(17.9)\end{array}$ & NT & $\begin{array}{l}\text { Zusman et al., } \\
\qquad 2006^{(18)}\end{array}$ \\
\hline São Luis/MA & 201 & $\begin{array}{l}\mathrm{VR} / \geq 36 \\
\text { weeks }\end{array}$ & $\begin{array}{c}\mathrm{TH}+\mathrm{CT} 10 \mu \mathrm{g} / \mathrm{mL}+\mathrm{NA} 15 \mu \mathrm{g} / \\
\mathrm{mL}\end{array}$ & $\begin{array}{c}41 \\
(20.4)\end{array}$ & $\begin{array}{c}\text { E (23.6) } \\
\text { DA }(25.4) \\
\text { CRO }(12.7)\end{array}$ & $\begin{array}{l}\text { Costa et al., } \\
2008^{(19)}\end{array}$ \\
\hline $\begin{array}{l}\text { Campinas/ } \\
\text { SP }\end{array}$ & 203 & $\begin{array}{c}\text { V/22-37 } \\
\text { weeks }\end{array}$ & $\mathrm{TH}$ & $\begin{array}{c}56 \\
(27.6)\end{array}$ & NT & $\begin{array}{l}\text { Nomura et al., } \\
2009^{(20)}\end{array}$ \\
\hline $\begin{array}{c}\text { Rio de } \\
\text { Janeiro/RJ }\end{array}$ & 3,929 & $\begin{array}{l}\mathrm{VR} / 35-37 \\
\text { weeks }\end{array}$ & $\mathrm{NU}$ & $\begin{array}{c}186 \\
(4.7)\end{array}$ & NT & $\begin{array}{l}\text { Costa et al., } \\
2010^{(21)}\end{array}$ \\
\hline $\begin{array}{c}\text { Juiz de Fora/ } \\
\text { MG }\end{array}$ & 221 & $\begin{array}{l}\mathrm{VR} /<\text { and } \\
\geq 37 \text { weeks }\end{array}$ & $\begin{array}{c}\mathrm{TH}+\mathrm{CN} 8 \mu \mathrm{g} / \mathrm{mL}+\mathrm{NA} 15 \mu \mathrm{g} / \\
\mathrm{mL}+\text { sodium azide } 0.02 \%\end{array}$ & $21(9.5)$ & $\begin{array}{l}\text { E (22.7) } \\
\text { DA (50) }\end{array}$ & $\begin{array}{l}\text { Castellano } \\
\text { Filho et al., } \\
201^{0(22)}\end{array}$ \\
\hline Maringá/PR & 102 & $\begin{array}{l}\mathrm{VR} / \geq 35 \\
\text { weeks }\end{array}$ & $\begin{array}{c}\text { HPTH } \\
\frac{\mathrm{TH}+\mathrm{CN} 8 \mu \mathrm{g} / \mathrm{mL}+\mathrm{NA} 15 \mu \mathrm{g} /}{\mathrm{mL}}\end{array}$ & $\begin{array}{c}25 \\
(24.5)\end{array}$ & NT & $\begin{array}{l}\text { Chaves Jr et al., } \\
2010^{(23)}\end{array}$ \\
\hline Sobral/CE & 213 & $\begin{array}{l}\mathrm{VR} />20 \\
\text { weeks }\end{array}$ & $\begin{array}{c}\mathrm{TH}+\mathrm{CN} 8 \mu \mathrm{g} / \mathrm{mL}+\mathrm{NA} 15 \mu \mathrm{g} / \\
\mathrm{mL}\end{array}$ & $9(4.2)$ & $\begin{array}{c}\text { AMP, KF, P (44.4) } \\
\text { E (33.3) } \\
\text { DA (77.8) } \\
\text { C (11.1) }\end{array}$ & $\begin{array}{l}\text { Linhares et al., } \\
\qquad 2011^{(24)}\end{array}$ \\
\hline Tubarão/SC & 118 & $\begin{array}{l}\text { VR/35-37 } \\
\text { weeks }\end{array}$ & NE & $\begin{array}{c}32 \\
(27.1)\end{array}$ & NT & $\begin{array}{l}\text { Kruk et al., } \\
2013^{(25)}\end{array}$ \\
\hline Tubarão/SC & 203 & $\begin{array}{l}\mathrm{VR} / \geq 35 \\
\text { weeks }\end{array}$ & $\begin{array}{c}\mathrm{TH}+\mathrm{CN} 8 \mu \mathrm{g} / \mathrm{mL}+\mathrm{NA} 15 \mu \mathrm{g} / \\
\mathrm{mL}\end{array}$ & $\begin{array}{c}41 \\
(19.7)\end{array}$ & NT & $\begin{array}{l}\text { Schörner et al., } \\
2014^{(26)}\end{array}$ \\
\hline Maringá/PR & 544 & $\begin{array}{l}\mathrm{VR} / \geq 35 \\
\text { weeks }\end{array}$ & $\begin{array}{c}\text { HPTH } \\
\mathrm{TH}+\mathrm{CN} 8 \mu \mathrm{g} / \mathrm{mL}+\mathrm{NA} 15 \mu \mathrm{g} / \\
\mathrm{mL}\end{array}$ & $\begin{array}{l}136 \\
(25)\end{array}$ & $\begin{array}{c}\text { E (8.1) } \\
\text { DA (5.9) } \\
\text { C (4.4) } \\
\text { TE }(82.3)\end{array}$ & $\begin{array}{l}\text { Melo et al., } \\
2016^{(27)}\end{array}$ \\
\hline $\begin{array}{l}\text { Londrina/ } \\
\text { PR }\end{array}$ & 2,901 & $\begin{array}{l}\text { VR/35-37 } \\
\text { weeks }\end{array}$ & Granada Broth & $\begin{array}{c}528 \\
(18.2)\end{array}$ & $\begin{array}{c}\mathrm{P}(0.4) \\
\mathrm{E}(10.2) \\
\mathrm{DA}(10.0)\end{array}$ & This study \\
\hline
\end{tabular}

$N$ : Number of pregnant women analyzed; n: number of positive cultures for GBS; V: vaginal; VR: vaginal-rectal; NE: not specified; NT: not tested; NU: not used; TH: Todd-Hewitt Broth; HPTH: Hitchens-Pike-Todd-Hewitt; AMP: ampicillin; P: penicillin G; CRO: ceftriaxone; KF: cephalothin; E: erythromycin; DA: clindamycin; CN: gentamicin; C: chloramphenicol; TE: tetracycline; NA: nalidixic acid; CT: colistin. 
Clindamycin, erythromycin, and vancomycin are alternatives for both pregnant women colonized with penicillin-resistant GBS or allergic to penicillin with high risk of anaphylaxis. ${ }^{(7)}$ The susceptibility for erythromycin and clindamycin between GBS isolated from these patients can also vary according to geographic location. In African countries, rates of erythromycin and clindamycin resistance ranging from $6.5 \%$ to $21.1 \%$ and $3.2 \%$ to $17.2 \%$, respectively, were reported among GBS isolates from pregnant women. ${ }^{(11,28)}$ Data from North America reported rates of resistance to erythromycin and clindamycin ranging from $27.4 \%$ to $36 \%$ and $27.4 \%$ to $33 \%$, respectively. ${ }^{(11,29)}$ High rates of GBS resistance for both antimicrobials were reported in Italy $32.2 \%$ for erythromycin and $43.8 \%$ for clindamycin $)^{(30)}$ and China $(78.6 \%$ for erythromycin and $64.3 \%$ for clindamycin) (WANG et al., 2015). ${ }^{(10)}$ In contrast, lower rates of resistance were detected in Swiss (14.6\% for erythromycin and $8.2 \%$ for clindamycin) $)^{(12)}$ and Saudi Arabia (15.7\% for erythromycin and $5.1 \%$ for clindamycin). ${ }^{(31)}$

Here, we detected resistance to erythromycin in 54 isolates $(10.2 \%)$ and, of those, $46(85.2 \%)$ were also resistant to clindamycin. Resistance only to erythromycin was observed in 8 isolates $(1.5 \%)$, while $7(1.3 \%)$ were resistant only to clindamycin (Table 1). Similar rates of erythromycin and clindamycin resistance between GBS colonizer of pregnant women were detect in a Public Health Service of Maringá city in northern Paraná, Brazil. ${ }^{(27)}$ Rates of resistance ranging from $0 \%$ to $14.3 \%$ and $7.7 \%$ to $12.2 \%$ for erythromycin and clindamycin, respectively were detected in studies performed in GBS isolated from pregnant women in Rio de Janeiro, Brazil. ${ }^{(32,33)}$ In contrast, high rates of resistance for both antimicrobials were detected in other Brazilian studies (Table 3).

\section{Conclusion}

In our region, resistance to penicillin between vaginal-rectal GBS colonizer of pregnant women is rare. However, we identified two penicillin-resistant GBS isolates in this study. In addition, a substantial number of GBS isolates resistant to clindamycin was also detected. These results highlight the importance of continuous surveillance of vaginal-rectal GBS colonization in pregnant women and monitoring antimicrobial resistance for proper IAP. In turn, these measures greatly contribute to the prevention of GBS early-onset diseases in neonates.

\section{Acknowledgements}

This study was supported by grants from DECIT/ SCTIE/MS/CNPq, "Fundação Araucária/SESA-PR" (Research Programm for "Sistema Único de SaúdePPSUS"/2011). A.E.B. Morguette was supported by student scholarship from CNPq. S.F. Yamada-Ogatta was supported by research fellowship from CNPq. E.S. Otaguiri and R.P. Biasi-Garbin were supported by student scholarships from CAPES.

\section{References}

1 Mccord N, Owen P, Powls A, Lunan B. A complete audit cycle of intrapartum group B Streptococcus prophylaxis. Health Bull. 2001 Jul;59(4):263-7

2 Hansen SM, Uldbjerg N, Kilian M, Sørensen UB. Dynamics of Streptococcus agalactiae colonization in women during and after pregnancy and in their infants. J Clin Microbiol. 2004 Jan; 42(1):83-9

3 Boyer KM, Gotoff SP. Prevention of early-onset neonatal group $\mathrm{B}$ streptococcal disease with selective intrapartum chemprophylaxis. N Engl J Med. 1985 Jun;314(26):1665-9

4 Verani JR, McGee L, Schrag, SJ. Prevention of perinatal group b Streptococcal disease. MMWR Morb Mortal Wkly Rep. 2010;59(10):1-36.

5 Embleton N, Wariyar U, Hey E. Mortality from early onset group B streptococcal infection in the United Kingdom. Arch Dis Child Fetal Neonatal Ed. 1999 Mar;80(2):F139-41

6 Evangelista ML, Freitas FT. Group B Streptococcus neonatal infection in an intensive care unit in Brazil: high fatality and missed opportunities for antibiotic prophylaxis. Braz J Infect Dis. 2015 Jan/Feb;19(1):98-9. doi: 10.1016/j.bjid.2014.06.007

7 Verani JR, Schrag SJ. Group B streptococcal disease in infants: progress in prevention and continued challenges. Clin Perinatol. 2010 Jun;37(2):375-92. doi: 10.1016/j.clp.2010.02.002 
8 Clinical and Laboratory Standards Institutr. Performance standards for antimicrobial susceptibility testing. M100-S22, M2-7 and M-7. Wayne, PA/; CLSI; 2012.

9 Kwatra G, Cunnington MC, Merrall E, Adrian PV, Ip M, Klugman KP et al. Prevalence of maternal colonisation with group B Streptococcus: a systematic review and meta-analysis. Lancet Infect Dis. 2016 Sep;16(9):1076-84. doi: 10.1016/ S1473-3099(16)30055-X

10 Wang $\mathrm{P}$, Tong JJ, Ma XH, Song FL, Fan L, Guo CM et al. Serotypes, antibiotic susceptibilities, and multi-locus sequence type profiles of Streptococcus agalactiae isolates circulating in Beijing, China. PloS One. 2015 Mar;10(3):e0120035. doi: 10.1371/journal. pone. 0120035

11 Berg BR, Houseman JL, Tersteeg ZE, Lebar WD, Newton DW. Antimicrobial susceptibilities of group B Streptococcus isolates from prenatal screening samples. J Clin Microbiol. 2014 Sep; 52(9):3499-500. doi: 10.1128/JCM.01781-14

12 Frohlicher S, Reichen-Fahrni G, Müller M, Surbek D, Droz S, Spellerberg B et al. Serotype distribution and antimicrobial susceptibility of group B streptococci in pregnant women: results from a Swiss tertiary centre. Swiss Med Wkly. 2014 Mar;144:w13935. doi: 10.4414/ smw.2014.13935

13 Otaguiri ES, Morguette AEB, Tavares ER, Santos PM, Morey AT, Cardoso JD et al. Commensal Streptococcus agalactiae isolated from patients seen at University Hospital of Londrina, Paraná, Brazil: capsular types, genotyping, antimicrobial susceptibility, and virulence determinants. BMC Microbiol. 2013 Dec;13: 297. doi: 10.1186/14712180-13-297

14 Nagano N, Kimura K, Nagano Y, Yakumaru H, Arakawa Y. Molecular characterization of group B streptococci with reduced penicillin susceptibility recurrently isolated from a sacral decubitus ulcer. J Antimicrob Chemother. 2009 Dec;64(6):1326-8. doi: $10.1093 / \mathrm{jac} / \mathrm{dkp} 374$
15 Benchetrit LC, Fracalanzza SE, Peregrino H, Camelo AA, Sanches LA. Carriage of Streptococcus agalactiae in women and neonates and distribution of serological types: a study in Brazil. J Clin Microbiol. 1982 May;15(5):787-90

16 Beraldo C, Brito ASJ, Saridakis HO, Matsuo T. Prevalence of vaginal and anorectal colonization by group B Streptococcus in pregnant women in the last three months of gestation. Rev Bras Ginecol Obstet. 2004 ago;26(7):543-9. doi: 10.1590/S0100-72032004000700006

17 Pogere A, Zoccoli CM, Tobouti NR, Freitas PF, D'Acampora AJ, Zunino JN. Prevalence of group B Streptococcus in pregnant women from a prenatal care center. Rev Bras Ginecol Obstet. 2005 Apr;27(4):174-80. doi: 10.1590/S010072032005000400003

18 Zusman AS, Baltimore RS, Fonseca SN. Prevalence of maternal group B streptococcal colonization and related risk factors in a Brazilian population. Braz J Infect Dis. 2006 Aug;10(4):242-6

19 Costa ALR, Lamy Filho F, Chein MBC, Brito LMO, Lamy ZC, Andrade KL. Prevalence of colonization by group B Streptococcus in pregnant women from a public maternity of Northwest region of Brazil. Rev Bras Ginecol Obstet. 2008 Jun;30(6):274-80. doi: 10.1590/ S0100-72032008000600002

20 Nomura ML, Passini Júnior R, Oliveira UM, Calil R. Group B Streptococcus maternal and neonatal colonization in preterm rupture of membranes and preterm labor. Rev Bras Ginecol Obstet. 2009 Aug;31(8):397-403. doi: 10.1590/S010072032009000800005

21 Costa NDL, Carvalho M, Pone SM, G Júnior S C. Beta-hemolytic Streptococcus in pregnant women and their newborn infants: a critical analysis of the protocol used at Fernandes Figueira Institute, Oswaldo Cruz Foundation, in Brazil. Rev Paul Pediatr. 2010 Jun;28(2):155-61. doi: 10.1590/ S0103-05822010000200005 
22 Castellano-Filho DS, Silva VL, Nascimento TC, Vieira MT, Diniz CG. Detection of group B streptococcus in brazilian pregnant women and antimicrobial susceptibility patterns. Braz. J. Microbiol. 2010 Dec;41(4):1047-1055. doi: 10.1590/S1517-83822010000400024.

23 Chaves M Jr, Pádua RA, Campanerut PA, Pelloso SM, Carvalho MD, Siqueira VL et al. Preliminary evaluation of Hitchens-Pike-ToddHewitt medium (HPTH) for detection of group B streptococci in pregnant women. J Clin Lab Anal. 2010;24(6):403-6. doi: 10.1002/jcla.20419

24 Linhares JJ, Cavalcante Neto PG, Vasconcelos JLM, Saraiva TV, Ribeiro AMF, Siqueira TM et al. Prevalence of the colonization by Streptococcus agalactiae in pregnant women from a maternity in Ceará, Brazil, correlating with perinatal outcomes. Rev Bras Ginecol Obstet. 2011 Dec;33(12):395400. doi: 10.1590/S0100-72032011001200004

25 Kruk CR, Feuerschuette OH, Silveira SK, Cordazo M, Trapani Júnior A. Epidemiologic profile of Streptococcus agalactiae colonization in pregnant women attending prenatal care in a city of southern of Brazil. Braz J Infect Dis. 2013 Nov-Dec;17(6):722-3. doi: 10.1016/j. bjid.2013.07.003

26 Schörner MA, May Feuershuette OH, Scheffr MC, Senna SG, Bazzo ML, Maurici R. Detection of Group B Streptococcus agalactiae from anorectal and vaginal screening tests. Clin Microbiol. 2014;3:169.

27 Melo SCCS, Santos NC, Oliveira M, Scodro RB, Cardoso RF, Pádua RA et al. Antimicrobial susceptibility of Streptococcus agalactiae isolated from pregnant women. Rev Inst Med Trop São Paulo. 2016 Nov;58:83. doi: 10.1590/ S1678-9946201658083

Bolukaoto JY, Monyama CM, Chukwu MO, Lekala SM, Nchabeleng M, Maloba MR et al. Antibiotic resistance of Streptococcus agalactiae isolated from pregnant women in Garankuwa, South Africa. BMC Res Notes. 2015 Aug;8:364. doi: 10.1186/s13104-015-1328-0
29 Teatero S, Ferrieri P, Martin I, Demczuk W, Mcgeer A, Fittipaldi N. Serotype distribution, population structure, and antimicrobial resistance of group B Streptococcus strains recovered from colonized pregnant women. J Clin Microbiol. 2017 Feb;55(2):412-22. doi: 10.1128/JCM.01615-16

30 Matani C, Trezzi M, Matteini A, Catalani C, Messeri D, Catalani C. Streptococcus agalactiae: prevalence of antimicrobial resistance in vaginal and rectal swabs in Italian pregnant women. Infez Med. 2016 Sep;24(3):217-21

31 Khan MA, Faiz A, Ashshi AM. Maternal colonization of group B Streptococcus: prevalence, associated factors and antimicrobial resistance. Ann Saudi Med. 2015 Nov-Dec;35(6):423-7. doi: 10.5144/0256-4947.2015.423.

32 Soares GC, Alviano DS, Santos GS, Alviano CS, Mattos-Guaraldi AL, Nagao PE. Prevalence of Group B Streptococcus serotypes III and V in pregnant women of Rio de Janeiro, Brazil. Braz. J Microbiol. 2014 Jan;44(3):869-72.

33 Barros RR, Souza AF, Luiz FB. Polyclonal spread of Streptococcus agalactiae resistant to clindamycin among pregnant women in Brazil. J Antimicrob Chemother. 2016 Jul;71(7):2054-6. doi: $10.1093 / \mathrm{jac} / \mathrm{dkw} 085$

Recebido em: 28 jul. 2017

Aceito em: 30 out. 2017 
Morguette, A. E. B.; et al. 